\title{
HUBUNGAN ANTARA TINGKAT PENGETAHUAN TENTANG IMPLANT DENGAN PEMAKAIAN KONTRASEPSI IMPLANT PADA AKSEPTOR DI BPS NY. HJ. FAROHAH DESA DUKUN GRESIK
}

\author{
Taqiyyah Barroh Thoyyib*, Yunik Windarti** \\ (UNUSA, FKK, Prodi D III Kebidanan - Jl. Smea 57 Surabaya) \\ Email : yunikwinda@unusa.ac.id
}

\begin{abstract}
The purposed to find out the relationship between the knowledge about implant and implant contraceptive used of acceptors at BPS Farohah Gresik. Implant is one of hormone contraceptive methode with high effectiveness. But, know fact that there were acceptors refused to use implant. The caused factor is the less off acceptors knowledge about implant. Therefore, this research was purposed to find out the relationship between the knowledge about implant and implant contraceptive used of acceptors at BPS Farohah Gresik. The type of this research was analytic by cross sectional methode. The population involved 42 acceptors of hormonal contraceptive who attended on June at BPS Farohah Gresik. 38 respondents were taken as the samples using simple random sampling technique. The independent variable was knowledge where as, the dependent one was the used of implant. Questionnaires was used to collect the data. Analyzed by using MannWhitney test with the significance level $\alpha=0,05$. The result of this research showed that most of respondents $(60,5 \%)$ had less knowledge and almost all respondents $(89,5 \%)$ did not use implant. Furthermore, the statistic test has obtarned $\mathrm{p}=0,039<\alpha=0,05$. So $\mathrm{H}_{0}$ was refused that there was a relationship between knowledge about implant and the used of implant contraceptive at BPS Farohah Gresik. The research concluded that the less of acceptors knowledge about implant. The used of this contraceptive is vower. Hence, the health workers should improve the counselling and implant extension to people.
\end{abstract}

Abstrak : Hubungan Antara Tingkat Pengetahuan tentang Implant dengan Pemakaian Kontrasepsi Implant pada Akseptor di BPS Ny. Hj. Farohah Desa Dukun Gresik. Implant merupakan salah satu dari metode kontrasepsi hormonal yang memiliki efektivitas tinggi, namun kenyataannya masih banyak akseptor enggan menggunakan implant. Salah satu penyebab adalah kurangnya pengetahuan akseptor tentang implant. Penelitian ini bertujuan untuk mengetahui hubungan antara tingkat pengetahuan tentang implant dengan pemakaian kontrasepsi implant pada akseptor di BPS Farohah Gresik. Desain penelitian analitik dengan metode cross sectional. Populasinya semua akseptor hormonal yang melakukan kunjungan pada bulan Juni di BPS Farohah Gresik sebesar 42 orang. Sampel sebesar 38 responden diambil dengan tehnik "simple random sampling". Variabel independent tingkat pengetahuan dan variabel dependent pemakaian kontrasepsi implant. Pengumpulan data menggunakan kuesioner. Data dianalisa menggunakan uji Mann-Whitney dengan tingkat kemaknaan $\alpha=0,05$. Hasil penelitian menunjukkan sebagian besar responden $(60,5 \%)$ berpengetahuan kurang dan hampir seluruh responden $(89,5 \%)$ tidak menggunakan implant. Hasil uji statistik didapatkan $\rho=0,039<\alpha=0,05$, maka $\mathrm{H}_{0}$ ditolak artinya ada hubungan antara tingkat pengetahuan tentang implant dengan pemakaian kontrasepsi implant di BPS Farohah Gresik. Simpulan dari penelitian ini adalah semakin kurang pengetahuan akseptor tentang implant maka semakin rendah jumlah pemakaian kontrasepsi tersebut. Sehingga Bagi tenaga kesehatan diharapkan dapat meningkatkan konseling dan penyuluhan kepada masyarakat tentang implant.

Kata kunci : Tingkat pengetahuan, pemakaian kontrasepsi implant 


\section{PENDAHULUAN}

Keluarga berencana adalah usaha untuk mengukur jumlah dan jarak anak yang diinginkan, salah satu cara agar rencana tersebut tercapai yaitu dengan pemakaian kontrasepsi. Adapun metode kontrasepsi ini dibagi menjadi tiga sesuai dengan efektivitasnya, yaitu metode kontrasepsi sederhana, metode kontrasepsi efektif, dan metode kontrasepsi mantap. Dari ketiga macam metode kontrasepsi diatas yang sangat dianjurkan dalam pemakaiannya adalah metode kontrasepsi efektif, yang dibagi menjadi dua yaitu non hormonal dan hormonal. Metode kontrasepsi hormonal terdiri dari tiga yaitu suntik, pil, dan implant. Namun yang memiliki banyak penggunanya adalah suntik dan pil. Sedangkan pada kenyataannya implant merupakan metode kontrasepsi hormonal yang memiliki efektivitas sangat tinggi serta memiliki angka kegagalan yang rendah. implant juga merupakan alat kontrasepsi yang sangat sesuai bagi pasangan usia subur yang ingin memakai kontrasepsi dalam jangka panjang untuk mengatur jarak kehamilan. Menurut BKKBN, program KB dengan penggunaan metode kontrasepsi jangka panjang masih kurang peminatnya termasuk implant. (BKKBN, 2009). Berdasarkan data yang diperoleh Badan Koordinasi Keluarga Berencana Nasional (BKKBN) Jawa Timur dan Gresik perihal pencapaian KB aktif hormonal pada tahun 2009, 2010, dan 2011 adalah sebagai berikut:

Tabel 1 Jumlah akseptor implan di Jawa Timur

\begin{tabular}{|c|c|c|c|c|c|c|}
\hline $\begin{array}{l}\text { Metode } \\
\text { kontraseps } \\
\text { homonal }\end{array}$ & & $\begin{array}{c}\text { Jumlah } \\
\text { Jawa } \\
\text { Timur }\end{array}$ & & & $\begin{array}{l}\text { Jumlah } \\
\text { Gresik }\end{array}$ & \\
\hline & 2009 & 2010 & 2011 & 2009 & 2010 & 2011 \\
\hline Pil & 1.318 .622 & 1.329 .544 & 1.341 .156 & 39.018 & 39.581 & 39.863 \\
\hline Suntik & 2.822 .286 & 2.894 .367 & 2.966 .486 & 107.386 & 108.893 & 201.082 \\
\hline Implant & 454.917 & 460.825 & 526.559 & 13.247 & 13.355 & 13.485 \\
\hline Jumlah & 4.595 .825 & 4.684 .736 & 4.834 .501 & 159.651 & 161.829 & 254.430 \\
\hline
\end{tabular}

Dari tabel diatas dapat dilihat bahwa jumlah akseptor implant di Jawa Timur dan Gresik jauh lebih rendah dibandingkan dengan kontrasepsi suntik dan pil. Hal inipun serupa dengan akseptor KB aktif hormonal di BPS Ny.Hj.Farohah, berdasarkan hasil survey pendahuluan pada tanggal 15 April 2013 adalah sebagai berikut :

Tabel 2 Pemakai alat kontrasepsi di BPS Ny. Hj Farohah :

\begin{tabular}{|l|r|r|r|}
\hline \multicolumn{1}{|c|}{ Metode } & & \multicolumn{1}{|c|}{ Jumlah } & \\
\hline Kontrasepsi & 2009 & 2010 & 2011 \\
\hline Suntik & 222 & 242 & 273 \\
Pil & 19 & 24 & 26 \\
Implant & $\mathbf{5}$ & 6 & 8 \\
\hline Jumlah & 246 & 262 & 307 \\
\hline
\end{tabular}

Dari beberapa tabel diatas dapat kita lihat bahwa pemakai alat kontrasepsi implant di Jawa Timur, kota Gresik, dan BPS Ny.Hj.Farohah Desa Dukun Gresik selama tahun 2009 - 2011 mengalami peningkatan tiap tahunnya, namun peningkatannya jauh lebih rendah dari metode kontrasepsi hormonal suntik dan pil. Padahal alat kontrasepsi implant sendiri memiliki efektivitas lebih tinggi dari alat kontrasepsi hormonal lain seperti suntik dan pil. Hasil studi pendahuluan yang dilakukan terhadap 9 akseptor pil \& suntik dengan cara wawancara pada tanggal 15 April 2013 mengenai kontrasepsi implant didapatkan hanya 2 akseptor yang tahu tentang implant, Sementara 7 yang lain tidak tahu tentang implant, bahkan mereka mengaku enggan untuk memilih implant karena takut saat pemasangan serta adanya rumor bahwa implant dapat berpindah tempat, harga alat kontrasepsi implant yang mahal dibanding alat kontrasepsi suntik atau pil serta 1 responden mengatakan bahwa KB susuk dilarang oleh agama. Rendahnya jumlah peminat akseptor implant dapat disebabkan karena beberapa faktor seperti ketidaktahuan peserta tentang kelebihan implant dimana pengetahuan tentang alat kontrasepsi merupakan pertimbangan dalam menentukan metode kontrasepsi yang digunakan, faktor sumber ekonomi yang berkaitan erat dengan kemampuan untuk membeli alat kontrasepsi yang digunakan, sejumlah faktor budaya dapat mempengaruhi 
klien dalam memilih metode kontrasepsi, faktor tingkat pendidikan tidak saja mempengaruhi kerelaan menggunakan $\mathrm{KB}$ tetapi juga pemilihan suatu metode, di berbagai daerah kepercayaan religius juga dapat mempengaruhi klien dalam memilih metode (Handayani, 2010). Rendahnya akseptor yang memilih alat kontrasepsi implant dapat mengakibatkan tingginya angka kegagalan pemakaian kontrasepsi. Sehingga dapat menimbulkan beberapa dampak, yaitu peningkatan angka kematian ibu dan anak, penurunan kesejahteraan keluarga, penurunan kapasitas sumber daya manusia, penurunan derajat kesehatan dan peningkatan masalah kesehatan reproduksi (Yetti \& Martini, 2012)

\section{METODE}

Desain penelitian yang digunakan adalah analitik dengan pendekatan yang digunakan adalah cross sectional, yaitu suatu penelitian dimana variabel independen (tingkat pengetahuan akseptor tentang implant) dan dependen (pemakaian kontrasepsi implant) diobservasi pada waktu yang sama. Populasi dalam penelitian adalah semua akseptor hormonal yang melakukan kunjungan pada bulan Juni di BPS Ny. Hj. Farohah Desa Dukun Gresik pada bulan Juni sebesar 42 orang kemudian diambel sampel sebesar 38 orang. Tehnik sampling dilakukan secara probability sampling dengan teknik simple random sampling dimana semua subyek mempunyai kesempatan yang sama untuk dijadikan sampel dengan cara acak.

Data dianalisis dengan menggunakan uji statistik Mann-whtney dengan menggunakan SPSS for Windows dan tingkat signifikasi $\alpha=0,05$. Ho ditolak bila $\mathrm{p}<\alpha$ yang berarti ada hubungan antara tingkat pengetahuan tentang implant dengan pemakaian kontrasepsi implant.

\section{HASIL DAN PEMBAHASAN}

Karakteristik responden berdasarkan tingkat pengetahuan
Tabel 3 Distribusi frekuensi responden berdasarkan tingkat pengetahuan di BPS Ny. Hj. Farohah pada bulan Juni 2013

\begin{tabular}{|c|c|c|}
\hline Pengetahuan & Frekuensi (n) & Persentase (\%) \\
\hline Baik & 3 & 7,9 \\
\hline Cukup & 12 & 31,6 \\
\hline Kurang & 23 & 60,5 \\
\hline Jumlah & 38 & 100 \\
\hline
\end{tabular}

Pada tabel 3 menunjukkan bahwa dari 38 responden sebagian besar $(60,5 \%)$ memiliki pengetahuan kurang.

Karakteristik responden berdasarkan pemakaian kontrasepsi implant

Tabel 4 Distribusi frekuensi responden berdasarkan pemakaian kontrasepsi implant di BPS Ny. Hj. Farohah pada bulan Juni 2013

\begin{tabular}{|c|c|c|}
\hline Pemakajan implant & Frekuensi (n) & Persentase (\%) \\
\hline$Y_{a}$ & 4 & 10,5 \\
\hline Tidak & 34 & 89,5 \\
\hline Jumlah & 38 & 100 \\
\hline
\end{tabular}

Pada tabel 4 menunjukkan bahwa dari 38 responden hampir seluruhnya $(89,5 \%)$ tidak menggunakan kontrasepsi implant.

Hubungan antara tingkat pengetahuan tentang implant dengan pemakaian kontrasepsi implant Tabel 5.Hubungan antara tingkat pengetahuan tentang implant dengan pemakaian kontrasepsi implant pada akseptor di BPS Ny. Hj. Farohah Desa Dukun Gresik pada bulan Juni 2013.

\begin{tabular}{|c|c|c|c|c|c|c|}
\hline \multirow[t]{3}{*}{ Pengetahuan } & \multicolumn{5}{|c|}{ Pemakaian kontrasepsi implant } & \multirow[t]{2}{*}{ Jumlah } \\
\hline & & $\mathrm{Ya}_{2}$ & & Tidak & & \\
\hline & n & $\%$ & $\mathrm{~N}$ & & $\%$ & $\sum(\%)$ \\
\hline Baik & 2 & 66,7 & 1 & & 33,3 & $3(100)$ \\
\hline Cukup & 1 & 8,3 & 11 & & 91,7 & $12(100)$ \\
\hline Kurang & 1 & 4,3 & 22 & & 95,7 & $23(100)$ \\
\hline Jumlah & 4 & 10,5 & 34 & & 89,5 & $38(100)$ \\
\hline
\end{tabular}

Berdasar tabel 5 menunjukkan menunjukkan bahwa dari 3 responden yang memiliki pengetahuan baik sebagian besar (66,7\%) menggunakan implant, dari 12 responden yang memiliki pengetahuan cukup hampir seluruhnya (91,7\%) tidak menggunakan implant sedangkan dari 23 
responden yang memiliki pengetahuan kurang hampir seluruhnya $(95,7 \%)$ tidak menggunakan implant.

Berdasarkan hasil uji Mann Whitney didapatkan nilai $\rho=0,039$ dan $\alpha=0,05$. Karena $\rho(0,039)<\alpha(0.05)$, maka hipotesis nihil $\left(\mathrm{H}_{0}\right)$ ditolak yang artinya ada hubungan antara tingkat pengetahuan tentang implant dengan pemakaian kontrasepsi implant pada akseptor dimana pemakaian kontrasepsi implant masih rendah jumlahnya.

\section{PEMBAHASAN}

\section{Tingkat Pengetahuan}

Berdasarkan tabel 3 didapatkan hasil bahwa dari 38 responden sebagian besar $(60,5 \%)$ memiliki pengetahuan kurang tentang implant. Kurangnya pengetahuan akseptor tentang implant dapat disebabkan karena beberapa hal, pertama kurangnya konseling yang dilakukan tenaga kesehatan pada calon akseptor baru tentang kontrasepsi implant, tenaga kesehatan cenderung hanya memberikan konseling tentang kontrasepsi yang akan dipilih oleh akseptor baru tersebut. Kedua minimnya sumber informasi tentang implant karena informasi mengenai implant merupakan salah satu sumber informasi yang susah didapatkan sehingga akseptor cenderung mencari informasi dari lingkungan sekitar yang menghasilkan persepsi salah tentang implant.

Hal ini sesuai dengan teori (Hartanto, 2004), seseorang yang kurang memanfaatkan pelayanan kesehatan dapat disebabkan karena kurangnya pengetahuan tentang kesehatan termasuk metode kontrasepsi.

Dari rekapitulasi kuesioner, diketahui masih banyak akseptor di BPS Ny.Hj. Farohah belum mengetahui tentang efektivitas implant, hal ini disebabkan karena beberapa akseptor percaya bahwa bahwa kontrasepsi yang dipilih yaitu pil dan suntik sangatlah efektif dibandingkan dengan kontrasepsi implant. Akseptor juga tidak mengetahui tentang pengembalian kesuburan, lebih mempercayai bahwa apabila menggunakan implant waktu pengembalian kesuburan implant sangat lama. Pengetahuan seseorang dipengaruhi beberapa faktor diantaranya umur, pendidikan, dan pekerjaan (Mubarak.W, 2007).

Periode umur 20-40 tahun tergolong dalam kelompok yang sudah matang dan dewasa. Pada umur 20-40 tahun seharusnya seseorang akan lebih mudah dalam memperoleh pengetahuan, namun pada kenyataannya tidak semua orang pada periode ini akan memperoleh pengetahuan yang baik termasuk pengetahuan mengenai kontrasepsi implant. Hal ini tidak sesuai dengan teori yang menyatakan bahwa pada umur 20-40 tahun kemampuan untuk berfikir seseorang semakin matang dan dewasa, terjadi akibat pematangan fungsi organ pada aspek psikologis, dan mental (Mubarak.W, 2007). Berarti terdapat faktor lain yang lebih mempengaruhi pengetahuan akseptor tentang implant selain faktor umur.

Tingkat pendidikan mempengaruhi pengetahuan seseorang termasuk pengetahuan tentang kesehatan. hal ini menyebabkan seseorang tidak dapat berfikir secara rasional sehing ga lebih mudah percaya dengan pendapat lingkungan sekitar tentang kontrasepsi implant tanpa mencoba untuk mendapatkan informasi yang lebih terpercaya. Hal tersebut sesuai dengan teori bahwa tingkat pendidikan yang rendah akan menghambat perkembangan sikap seseorang terhadap nilainilai yang baru dikenalkan (Notoatmodjo, 2006).

Seorang ibu yang bekerja seharusnya memiliki lebih banyak pengetahuan dibandingkan dengan seorang ibu yang tidak bekerja, namun pada kenyataannya pengetahuan ibu yang bekerja dan tidak bekerja sama-sama kurang terutama pengetahuan tentang implant. Hal ini tidak sesuai dengan teori yang mengatakan bahwa pekerjaan dapat menjadikan seseorang memperoleh pengalaman dan pengetahuan baik secara langsung maupun secara tidak langsung (Notoatmodjo, 2006). 
Pemakaian Implant

Berdasarkan tabel 4 menunjukkan bahwa dari 38 responden hampir seluruhnya $(89,5 \%)$ tidak menggunakan implant. Hal tersebut menunjukkan bahwa responden yang menggunakan implant masih rendah. Rendahnya pemakaian implant disebabkan beberapa faktor, yaitu usia, sikap, pendidikan dan pengetahuan. Serta sebagian masyarakat disana mempercayai mitos bahwa implant dapat berpindah tempat, sehingga mereka lebih memilih kontrasepsi lain karena mengikuti riwayat kontrasepsi terdahulu.

Dari rekapitulasi kuesioner, 14 akseptor yang menggunakan pil 10 diantaranya memiliki alasan bahwa menggunakan pil karena murah, 20 akseptor yang menggunakan suntik 11 diantaranya memiliki alasan bahwa menggunakan suntik karena praktis, da Pengetahuan antara satu wanita dengan wanita lain bervariasi, pengetahuan dapat mempengaruhi dalam pemakaian kontrasepsi. Berdasarkan hasil penelitian menunjukkan bahwa dari 23 responden yang memiliki pengetahuan kurang hampir seluruhnya $(95,7 \%)$ tidak menggunakan implant. Tingkat pengetahuan kurang pada seorang wanita mempengaruhi pola pikir atau pemahaman seseorang tentang implant. Sehingga pada seorang wanita dengan tingkat pengetahuan kurang memiliki kecenderungan untuk tidak menggunakan implant karena adanya persepsi yang salah tentang implant mulai dari rasa sakit saat pemasangan dan pasca pemasangan hingga efektivitas implant dan waktu pengembalian kesuburan implant. Hal ini sesuai dengan teori semakin baik pengetahuan seseorang maka kesadaran untuk memperoleh pelayanan kesehatan termasuk kontrasepsi yang memiliki efektivitas tinggi akan semakin meningkat (Glasier dan Gebbie, 2005).

Dari 4 akseptor yang menggunakan implant 2 diantaranya memiliki alasan menggunakan implant karena permintaan suami dan 2 yang lain memiliki alasan menggunakan implant karena praktis. Jadi dapat disimpulkan bahwa faktor pengetahuan bukanlah salah satu faktor yang menyebabkan seorang akseptor enggan menggunakan implant.

Seorang wanita multipara cenderung lebih memilih menggunakan pil dan suntik dibandingkan menggunakan implant, padahal implant memilki efektivitas lebih tinggi dibanding dengan suntik dan pil. Serta implant dapat digunakan dalam jangka panjang untuk mengatur jarak kehamilan. Hal ini tidak sesuai dengan teori yang menyatakan bahwa semakin tinggi paritas yaitu ibu yang memiliki anak lebih dari empat seorang wanita maka beberapa metode efektif jangka panjang (AKDR, implan, MOW, MOP) dapat digunakan untuk menghentikan terjadinya kehamilan di masa mendatang (Glasier dan Gebbie, 2005).

Hubungan antara tingkat pengetahuan tentang implant dengan pemakaian kontrasepsi implant pada akseptor

Setelah dilakukan tabulasi silang antara kedua variabel dari penghitungan uji statistik mann-Whitney didapatkan nilai $\mathrm{p}=$ 0,039 dan $\alpha=0,05$. Karena $\mathrm{p}(0,039)<\alpha$ (0.05), maka hipotesis nihil $\left(\mathrm{H}_{0}\right)$ ditolak yang artinya ada hubungan antara tingkat pengetahuan tentang implant dengan pemakaian kontrasepsi implant pada akseptor. Hal ini ditunjukkan pada tabel 5 menunjukkan bahwa dari 3 responden yang memiliki pengetahuan baik sebagian besar $(66,7 \%)$ menggunakan implant, dari 12 responden yang memiliki pengetahuan cukup sebagian besar $(91,7 \%)$ tidak menggunakan implant sedangkan dari 23 responden yang memiliki pengetahuan kurang hampir seluruhnya (95,7\%) tidak menggunakan implant. Pengetahuan akseptor yang kurang tentang implant dapat mengakibatkan kesalahan persepsi serta sikap akseptor terhadap kontrasepsi implant tersebut, sehingga menyebabkan rendahnya jumlah akseptor implant.

Pengetahuan antara satu wanita dengan wanita lain bervariasi, pengetahuan dapat 
mempengaruhi dalam pemakaian kontrasepsi. Berdasarkan hasil penelitian menunjukkan bahwa dari 23 responden yang memiliki pengetahuan kurang hampir seluruhnya (95,7\%) tidak menggunakan implant. Tingkat pengetahuan kurang pada seorang wanita mempengaruhi pola pikir atau pemahaman seseorang tentang implant. Sehingga pada seorang wanita dengan tingkat pengetahuan kurang memiliki kecenderungan untuk tidak menggunakan implant karena adanya persepsi yang salah tentang implant mulai dari rasa sakit saat pemasangan dan pasca pemasangan hingga efektivitas implant dan waktu pengembalian kesuburan implant. Hal ini sesuai dengan teori semakin baik pengetahuan seseorang maka kesadaran untuk memperoleh pelayanan kesehatan termasuk kontrasepsi yang memiliki efektivitas tinggi akan semakin meningkat (Glasier dan Gebbie, 2005).

Selain itu dari 3 responden yang memiliki pengetahuan baik sebagian besar (66.7\%) menggunakan implant. Karena pengetahuan yang baik tentang implant akan mempengaruhi seorang wanita untuk menggunakan kontrasepsi implant. Hal ini dikarenakan responden mengetahui bahwa kontrasepsi implant memiliki efektivitas tinggi, dapat digunakan selama 3 tahun serta tidak memerlukan kunjungan rutin ke tenaga kesehatan. Hal ini sesuai dengan teori dari BKKBN (2005), yang mengatakan bahwa pengetahuan yang baik tentang $\mathrm{KB}$ akan mempengaruhi pemakaian kontrasepsi yang tepat dan dengan suatu perilaku atau didasari oleh pengetahuan serta mengerti manfaat dari kontrasepsi dan membuat ibu dengan sendirinya memutuskan kontrasepsi yang cocok untuk digunakan.

Rendahnya jumlah masyarakat yang menggunakan Implant sebagai alat kontrasepsi dapat disebabkan karena keterbatasan pengetahuan seseorang tentang implant. Untuk mengatasi hal tersebut petugas kesehatan dapat melakukan penyuluhan dan membagikan leaflet kepada akseptor tentang implant. Hal ini diperkuat oleh pernyataan menurut Notoatmodjo “ apabila penerimaan perilaku baru atau adopsi perilaku melalui proses dan didasari oleh pengetahuan, kesadaran, dan sikap yang positif, maka perilaku tersebut akan bersifat langgeng (long lasting). Sebaliknya apabila perilaku itu tidak didasari oleh pengetahuan dan kesadaran maka tidak akan berlangsung lama"' (Notoatmodjo, 2003).

\section{SIMPULAN}

Akseptor di BPS Ny.Hj Farohah Desa Dukun Gresik sebagian besar memiliki pengetahuan kurang tentang implant.

Akseptor di BPS Ny.Hj Farohah Desa Dukun Gresik hampir seluruhnya tidak menggunakan kontrasepsi implant.

Ada hubungan antara tingkat pengetahuan tentang implant dengan pemakaian kontrasepsi implant pada akseptor di BPS Ny.Hj Farohah Desa Dukun Gresik.

\section{DAFTAR RUJUKAN}

Arikunto, Suharsini. 2006. Prosedur Penelitian Suatu Pendekatan Praktis. Jakarta: PT. Bumi Aksara

BKKBN. 2009. Evaluasi Hasil Pencapaian Program KB Nasional Bulan November 2009 Provinsi Jawa Timur. Surabaya: BKKBN

BKKBN. 2010. Evaluasi Hasil Pencapaian Program KB Nasional Bulan November 2010 Provinsi Jawa Timur. Surabaya: BKKBN

BKKBN. 2011. Evaluasi Hasil Pencapaian Program KB Nasional Bulan November 2011 Provinsi Jawa Timur. Surabaya: BKKBN

Friedman. 2004. Keperawatan Keluarga. Jakarta: EGC

Glasier, Anna dan Ailsa, Gebbie. 2005. Keluarga Berencana dan Kesehatan Reproduksi. Jakarta: EGC 
Handayani, Sri. 2010. Buku Ajar Pelayanan

Keluarga Berencana. Jakarta: Pustaka

Sinar Harapan

Hartanto, Hanafi. 2010. Keluarga Berencana dan Kontrasepsi. Jakarta: Pustaka Sinar Harapan

Hidayat, Alimul. 2010. Metode Penelitian dan Tehnik Analisa Data. Jakarta: Salemba Medika

Martini dan Anggraini, Yetti. 2012. Pelayanan Keluarga Berencana. Jakarta: Rohima Press

Mochtar, Rustam. 2005. Sinopsis Obstetri. Jakarta: EGC

Mubarak, Wahid Iqbal. 2007. Promosi Kesehatan. Jogjakarta: Graha Ilmu

Notoadmodjo, Soekidjo. 2005. Promosi Kesehatan Teori dan Aplikasi. Jakarta: PT.Bhineka Cipta

Notoadmodjo, Soekidjo. 2006. Pendidikan dan Perilaku Kesehatan. Jakarta: PT.Bhineka Cipta

Notoadmodjo, Soekidjo. 2010. Metodologi Penelitian Kesehatan. Jakarta: PT.Bhineka Cipta

Nursalam. 2008. Konsep dan Penerapan Metodologi Penelitian Ilmu Keperawatan. Jakarta: Salemba Medika

Saifuddin, Abdul Bari. 2007. Buku Panduan Praktis Pelayanan Maternal dan Neonatal. Jakarta: Yayasan Bina Pustaka Sarwono Prawirohardjo

Sardjunani, Nina. 2012. Arah Pembangunan Kependudukan dan Keluarga Berencana dalam RKP 2012 dan Rancangan RKP 2013. Jakarta: Badan Perencanaan Pembangunan Nasionbal

Sujiyatini. 2011. Panduan Lengkap Pelayanan KB Terkini. Jogjakarta: Nuha Medika Sulistyawati, Ari. 2011. Pelayanan Keluarga Berencana. Jakarta: Salemba Medika

Speroff, L. Dan Darney, P. 2003. Pedoman Klinis Kontrasepsi. Jakarta: EGC

Wiknjosastro, Hanifa, 2005. Ilmu kebidanan. Jakarta: Yayasan Bina Pustaka Sarwono Prawiroharjo 